\title{
ZAKAT SEBAGAI INSTRUMEN FISKAL DALAM MENUTUPI GOVERMENT EXPENDITURE DI INDONESIA
}

\author{
Tsaniyatul Haliyah, Ridan Muhtadi, Gancar Candra Premananto \\ Departemen Manajemen, Fakultas Ekonomi dan Bisnis, \\ Universitas Airlangga. \\ Email: nianio.haliyah@yahoo.com ridanmuhtadi@gmail.com
}

\begin{abstract}
The potential of zakat which is large in the country up to now has not been utilized by the Indonesian government to improve people's welfare. A new strategy is needed so that the potential of zakat in Indonesia can be absorbed optimally and distributed according to sharia provisions and community needs. This study aims to try to offer an idea to make zakat as an instrument of fiscal policy in Indonesia, namely to enter zakat into the posture of the Indonesian state budget, the aim of which is to optimize the absorption of zakat in the country and on its distribution target. The strategy that the authors offer to realize this is through reforming the regulatory aspects, making the structure and position of a more strategic zakat institution, namely by forming a directorate general of zakat, and entering the state budget posture zakat, namely the zakat receipt post at the receipt of non-tax revenues, and zakat expenditure posts are in the state expenditure post for poverty alleviation. Therefore, political will is needed in order to realize zakat as an instrument of fiscal policy in Indonesia.
\end{abstract}

Keywords: Zakat, Fiscal Policy, Poverty, Regulation, State Budget, Political Will

\section{PENDAHULUAN}

Dalam Islam dikenal Baitul Mal sebagai lembaga yang menjadi sentral pengaturan fiskal kenegaraan. Baitul Mal berperan dalam mengatur penerimaan dan pengeluaran negara pada Masa Rasulullah dan dinasti pemerintahan Islam selanjutnya. Konsep Baitul Mal secara umum adalah bagaimana menjaga pengeluaran negara agar seimbang dengan pendapatan negara (balanced budget).

Dalam sebuah riwayat, Qubaishah Ibnul Mukhariq pernah mendatangi Rasulullah SAW untuk mengadukan ajuan tentang bayaran diyat dan hutang. Rasulullah bersabda "tunggulah terlebih dahulu, sehingga zakat datang kepada kita"1. Dalam riwayat ini kita dapat mengetahui bahwa sikap Rasulullah adalah

\footnotetext{
1 Karim,Adiwarman A.2004.Sejarah Pemikiran Ekonomi Islam.Jakarta:PT Grafindo Persaea,phlm.29
} 
beliau tidak mengeluarkan uang negara di muka sebelum pemasukan datang apalagi sampai melakukan hutang. Meskipun dalam Islam hutang diperbolehkan namun tidak dianjurkan dalam Islam.

Dalam pengelolaan keuangan Negara, selain anti berhutang Rasulullah SAW juga menerapkan kebijakan balanced budget (keseimbangan antara penerimaan dan pengeluaran). Dr. Abdullah Asy-Syaikh Mahmud Ath-Thahir pakar ekonomi Islam dari Universitas King Sau'ud dalam Muqadimah fi Iqtishaijat Al-Maliyah Al-Ammah menilai bahwa strategi balance budget sudah diterapkan pada masa Rasulullah SAW. Begitupun juga pada masa Umar bin Khattab (13$23 \mathrm{H} / 634-644 \mathrm{M}$ ) dimana pada masa beliau keuangan publik diurus lebih serius². Kekhalifahan memiliki buku induk yang mendata rencana anggaran, pemasukan dan pengeluaran negara yang dihitung tahunan seperti praktek yang kita saksikan dalam konsep APBN modern saat ini'.

Begitupun juga yang terjadi ketika masa kepemimpinan Umar Bin Abdul Azis $(717-720 \mathrm{H})$ kekhalifahan 'pusing' karena tidak menemukan orang miskin di negara Islam. Sebagaimana diriwayatkan Athiyah bin Qais, khalifah Umar Bin Abdul Azis memerintahkan Abdul Hamid bin Abdurrahman, menteri yang mengurus zakat kekhalifahan, yang tengah berada di Irak untuk membagikan harta kepada kaum miskin. Sebelumnya khalifah menemukan kelebihan harta di kas negara. Lantas Abdul Hamid kerepotan, "sesungguhnya aku telah membagikan gaji dan bagian harta itu kepada umat manusia. Tetapi di dalam Baitul Mal masih terdapat sisa”. Inilah yang menjadi salah satu catatan sejarah bahwa konsep kebijakan fiskal yang ada dalam Islam membawa kesejahteraan bagi umat manusia.

Konsep keuangan publik yang telah dicontohkan oleh Rasulullah SAW dan kekhalifahan Islam ini sebenarnya dapat menjadi pertimbangan untuk diadopsi dalam sistem keuangan publik di negara kita. Dengan potensi zakat yang sangat besar yang dimiliki oleh negara kita, maka seharusnya negara tidak perlu berhutang untuk menutupi defisit APBN yang saat ini terjadi.

Zakat memiliki peran strategis dalam kesejahteraan umat, khususnya untuk pengentasan kemiskinan. Hal ini dikarenakan zakat memiliki fungsi distribusi harta yang bertujuan untuk memenuhi kebutuan dasar si miskin dan memperbaikit taraf hidupnya sehingga kelak diharapkan dia dapat bertindak menjadi muzakki (orang yang mengeluarkan zakat) bukan lagi seorang mustahik

\footnotetext{
2 Sharing, Mengelola Kenangan Publik. Secara Islami. Edisi 35 thn IV November 2009

${ }^{3}$ Sharing, Mengelola Keuangan Publik. Secara Islami. Edisi 35 thn IV November 2009
} 
Akan tetapi, potensi zakat yang besar di Indonesia saat ini belum dikelola dengan tepat sehingga belum mampu memberikan dampak signifikan dalam pengentasan kemiskinan. Padahal diperkirakan potensi zakat setiap tahunnya di Indonesia hingga Rp300 triliun ${ }^{4}$. Seharusnya zakat dapat dijadikan sebagai instrumen kebijakan fiskal di Indonesia sehingga menambah pemasukan APBN dan meningkatkan alokasi dana untuk pengentasan kemiskinan. Karena selama ini APBN selalu defisit dan selalu ditutupi oleh hutang.

Untuk menutup defisit pada APBN pemerintah membuka opsi pendanaan melalui empat sumber. Pertama, pinjaman luar negeri dengan persyaratan lunak dan jangka panjang. Kedua, mengutamakan penerbitan Surat Berharga Negara (SBN) rupiah di pasar dalam negeri. Ketiga, membuka akses pembiayaan di pasar internasional seperti obligasi dan sukuk global. Sementara itu total utang yang diperoleh tahun ini ditargetkan sebesar Rp214,139 triliun ${ }^{5}$. Padahal disisi lain, peningkatan anggaran untuk pengentasan kemiskinan yang ditutup melalui hutang ini belum memberikan dampak signifikan terhadap penurunan angka kemiskinan di Indonesia. padahal jika kita tinjau dari sisi ekonomi Islam, hutang adalah hal yang harus dihindari meskipun diperbolehkan.

Defisit yang sering terjadi dalam APBN seharusnya mendorong pemerintah untuk melakukan strategi baru, yakni dengan melakukan imbalance budget (surplus budget) agar fungsi alokasi dapat maksimal dan pemerintah tidak perlu lagi berhutang untuk menutupi defisit anggaran yang sering terjadi pada APBN. Hutang harus terus dikurangi bahkan bila perlu dihilangkan sehingga negara tidak lagi terbebani dengan hutang dan bunga yang sangat memberatkan negara dan masyarakat.

Mengenai sumber penerimaan negara, selama ini negara kita hanya masih mengandalkan pajak sebagai tumpuan penerimaan negara padahal sumber-sumber pendapatan secara Islami, salah satunya adalah zakat memiliki potensi yang besar. Seharusnya potensi ini dapat dimasukkan ke dalam sumber penerimaan negara sehingga dapat menambah pundi-pundi kas negara. Dengan demikian upaya untuk mengoptimalisasikan penerimaan dari sektor zakat harus dilakukan disamping peranan distribusi zakat dalam pengurangan angka kemiskinan yang sudah terbukti secara historis dan teoritis.

\section{Gambar 1.}

\footnotetext{
${ }^{4}$ www.Baznas.go.id

${ }^{5}$ www.badankebijakanfiskal.go.id 


\section{Kerangka Berpikir}

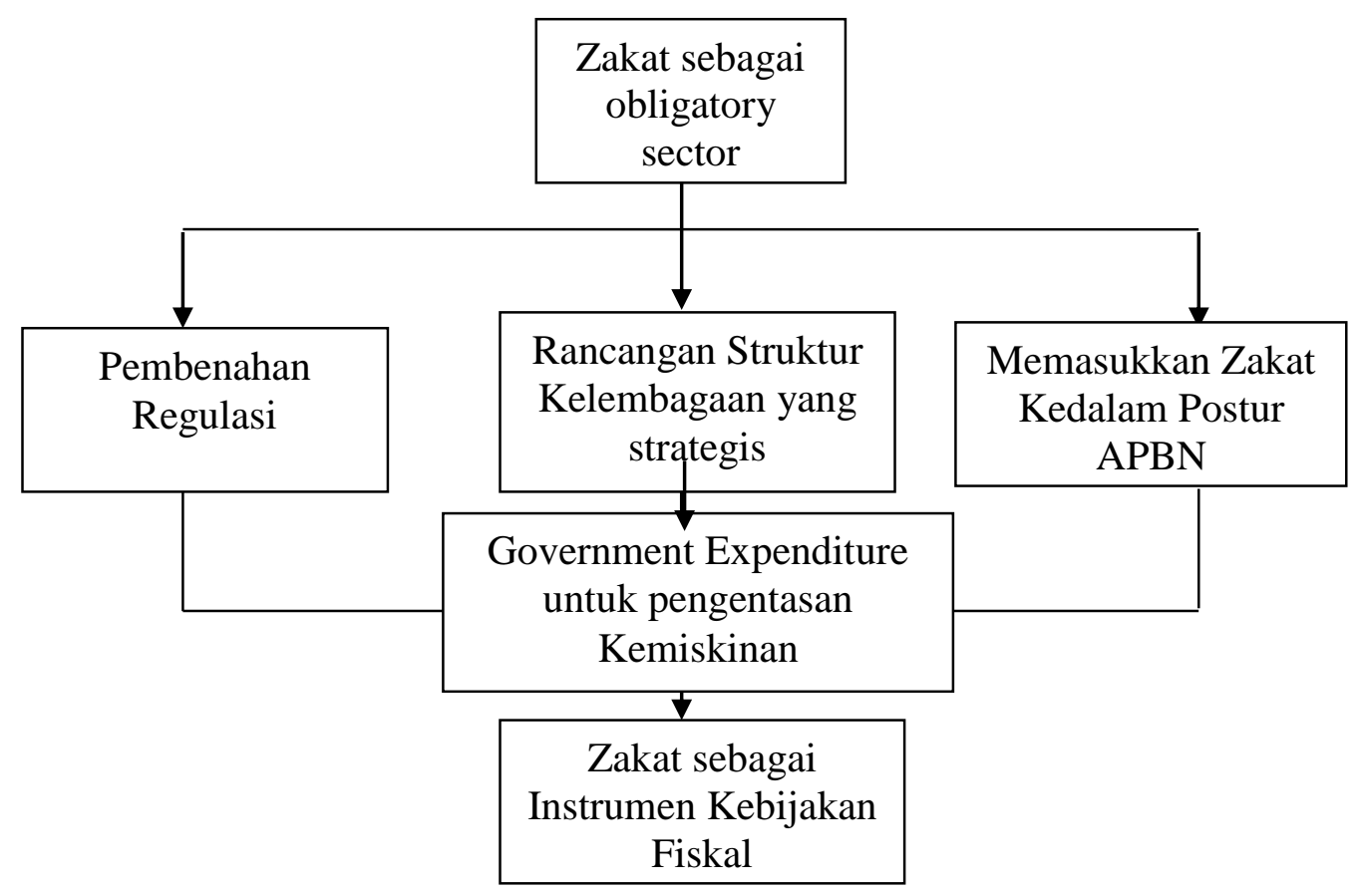

Sumber: Olahan Penulis

Berdasarkan uraian diatas, maka tujuan dalam tulisan ini, yakni menjelaskan Pengeluaran Pemerintah dalam APBN Untuk Pengentasan Kemiskinan dan implikasinya dalam menurunkan Angka Kemiskinan. Menjelaskan peran Zakat Sebagai Instrumen Fiskal Islam untuk Pengentasan Kemiskinan. Menjelaskan Potensi Zakat di Indonesia dan Potensinya dalam Pengentasan Kemiskinan di Indonesia. Menjelaskan Faktor-Faktor Penyebab Kurang Optimalnya Penyerapan dana Zakat di Indonesia. Menjelaskan Konsep dan Strategi untuk menjadikan Zakat Sebagai Instrumen Kebijakan Fiskal di Indonesia untuk Pengentasan kemiskinan.

\section{Teorisasi Zakat dan Instrumen fiskal Islam \\ 1. Zakat dan Fungsi Zakat}

Agama Islam mengajarkan bahwa seluruh kekayaan yang dimiliki hanyalah titipan Allah yang mana di dalamnya ada hak untuk orang-orang yang kurang mampu. Hal ini dijelaskan dalam firman Allah: 
"Berimanlah kamu kepada Allah dan Rasul-Nya dan nafkabkanlah sebagian dari bartamu yang Allah telah menjadikan kamu menguasainya. Maka orang-orang yang beriman di antara kamu dan menafkabkean (sebagian) dari hartanya memperoleh pahala yang besar." (QS. Al-Hadiid:7)

Karena itu, untuk mendistribusikan kekayaan maka setiap penganut agama Islam diwajibkan untuk mengeluarkan zakat sebagaimana dijelaskan dalam al-Quran surat 59 ayat 7. Zakat adalah rukun Islam ketiga setelah syahadat dan shalat sehingga kedudukannya sangat penting. Selain itu Allah menjamin balasan yang luar biasa bagi umat Islam yang menunaikan zakatnya, hal ini sangat jelas diterangkan dalam QS. Al-Baqarah ayat 261.

"Perumpamaan (nafkah yang dikeluarkan oleh) orang-orang yang menafkabkan bartanya di jalan Allah adalah serupa dengan sebutir benih yang menumbubkean tujub bulir, pada tiap-tiap bulir seratus biji. Allah melipat gandakan (ganjaran) bagi siapa yang Dia kehendaki. Dan Allah Maha Luas (karunia-Nya) lagi Maha Mengetabui." (QS. Al Baqarah:261)

Ditinjau dari segi bahasa kata zakat berasal dari bahasa arab, yaitu zaka (masdar) yang berarti berkah, tumbuh, bersih dan baik. Sedangkan menurut istilah fiqih, zakat berari sejumlah harta tertentu yang dikeluarkan dari barta tertentu untuk golongan tertentu .

Definisi "tertentu" menunjukkan bahwa ada aturan tertentu dalam penentuan jumlah zakat, harta yang wajib dizakati, orang yang wajib mengeluarkan zakat (muгakkel), orang yang menerima zakat (mustabiq) yang telah di tetapkan dalam al-Quran sebagai pedoman utama ajaran agama Islam.

Umat islam dalam kehidupannya mengenal dua istilah zakat, yaitu zakat fitrah dan zakat mal. Zakat fitrah dalah zakat yang wajib dikeluarkan oleh umat Islam yang memenuhi syarat pada saat bulan puasa (ramadhan), sedangkan zakat mal adalah zakat yang wajib dikeluarkan umat Islam yang memenuhi syarat dari hartanya yang telah mencapai satu nishab (ukuran tertentu dari harta yang wajib dizakati ) maupun satu baul (satu tahun). Keduanya merupakan fardbu, ain (diwajibkan bagi setiap individu umat islam). Sebagaimana yang disebutkan dalam Surah At-Taubah ayat 103 bahwa zakat harus diambil oleh pemimpin atau negara dengan sistem yang legal dan efektif.

"Ambillah zakat dari sebagian barta mereka, dengan zakat itu kamu membersibkan dan mensucikan mereka dan mendoalab untuk. mereka. Sesunggubnya doa kamu itu (menjadi) ketenteraman jiwa bagi mereka. dan Allah Maha mendengar lagi Maha mengetabui”.

\footnotetext{
${ }^{6}$ Qardawi, Yusuf. 1999. Hukum Zakat. Bandung: Mizan.hlm 34
} 
Adapun jenis harta yang wajib dizakati, al-Quran hanya merumuskannya secara umum, Dr. Yusuf Qardawi dalam bukunya bukum rakat menjelaskan beberapa jenis kekayaan yang wajib dizakati, antara lain: emas dan perak, tanaman dan buah-buahan, usaha, barang-barang tambang. Selain itu Utomo ${ }^{7}$ (2006), menjelaskan bahwa jenis kekayaan tersebut harus memenuhi beberapa syarat, yaitu;

a. harta yang halal dan tayyiban (baik bagi kesehatan orang yang mengkonsumsinya),

b. harta produktif dan berpotensi produktif,

c. milik penuh dan berkuasa, menggunakannya,

d. mencapai nishab (standar minimal harta yang dikenakan zakat),

e. surplus dari kebutuhan primer dan terbebas dari hutang, dan

f. haul (sudah berlalu setahun).

lain

Adapun syarat-syarat yang harus dipenuhi orang yang wajib zakat antara

a. beragama Islam,

b. aqil, berakal dan mampu membedakan antara yang baik dan yang buruk,

c. baligh, mencapai usia wajib melaksankan ajaran Islam umumnya diatandai dengan kematangan seksual, dan

d. memiliki harta yang wajib dizakati dan mencapai satu nishab atau satu haul.

Sedangkan golongan yang berhak menerima zakat sebagaimana disebutkan dalam Q.S. At-Taubah ayat 58-60, adalah sebagai berikut;

a. orang fakir, orang yang tidak mampu memenuhi kebutuhan pokoknya dan tidak memiliki mata pancaharian,

b. orang miskin, orang yang memilki mata pencarian namun tidak mencukupi untuk memenuhi kebutuhan pokoknya,

c. amil zakat, orang yang membantu mengumpulkan, mengelola dan menyalurkan zakat,

d. mi allaf, orang yang baru masuk Islam,

e. budak, orang yang tidak merdeka,

f. gharimin, orang yang berhutang untuk kemaslahatan dirinya ataupun kemaslahatan orang lain dan memenuhi syarat untuk menerima zakat,

g. fii sabilillah, orang yang berjuang di jalan Allah, dan

h. ibnu sabil, orang yang dalam perjalanan dan tidak mampu memenuhi kebutuhan pokoknya.

${ }^{7}$ Utomo, S.2006.Zakat dan Pembangunan.Jakarta:Perbit Pustaka

${ }^{8}$ Hidayat, Ach. Syaful. 2010. Analisis Tata Kelola dan Distribusi Zakat Pada Lembaga.Jakarta:Global 
Semua yang tersebut diatas jika memenuhi syarat yang telah ditentukan dalam syariat Islam maka berhak untuk menerima zakat. Untuk lebih jelasnya bisa dilihat di buku Hukum Zakat yang ditulis oleh DR. Yusuf Qardhawi'.

Sedangkan fungsi zakat meliputi antara lain;

a. mengangkat derajat fakir miskin,

b. membantu memecahkan masalah para gharimin, ibnu sabil dan mustabiq lainnya,

c. membentangkan dan membina tali persaudaraan sesama umat Islam dan manusia pada umumnya,

d. menghilangkan sifat kikir dan laba para pemilik harta,

e. menghilangkan sifat dengki dan iri (kecemburuan sosial) dari hati orangorang miskin,

f. menjembatani jurang antara si kaya dengan si miskin di dalam masyarakat (pemerataan dan pengentasan kemiskinan),

g. mengembangkan rasa tanggung jawab sosial pada diri seseorang terutama yang memiliki harta,

h. mendidik manusia untuk disiplin menunaikan kewajiban dan menyerahkan hak orang lain padanya, dan

i. menjadi sarana pemerataan pendapatan untuk mencapai keadilan.

\section{Kebijakan Fiskal dan Tujuannya}

Menurut Wolfson sebagaimana dikutip Suparmoko ${ }^{10}$. Kebijakan fiskal (fiskal policy) merupakan tindakan-tindakan pemerintah untuk meningkatkan kesejahteraan umum melalui kebijakan penerimaan dan pengeluaran pemerintah, mobilisasi sumberdaya, dan penentuan harga barang dan jasa dari perusahaan.

Sedangkan menurut Samuel dan Nordhaus kebijakan fiskal adalah ${ }^{11}$ : "Proses pembentukan perpajakan dan pengeluaran masyarakat dalam upaya menekan fluktuasi siklus bisnis, dan ikut berperan dalam menjaga pertumbuhan ekonomi, penggunaan tenaga kerja yang tinggi, bebas dari laju inflasi yang tinggi dan berubah-ubah".

Musgrave dalam hal ini mengatakan, Kebijakan fiskal adalah Setiap tindakan perpajakan dan pengeluaran tertentu untuk mempengaruhi perekonomian dengan tiga cara: alokasi, distribusi dan stabilisasi

\footnotetext{
${ }_{9}^{9}$ Qardawi, Yusuf. 1999. Hukum Zakat. Bandung: Mizan.hlm 34

${ }^{10}$ M.Suparmok, Keuangan Negara Dalam Teori dan Praktek, Cet.VII, BPFE, Yogyakarta, 1997, Hlm.256

${ }^{11}$ Paul A.Samuelson dan wiliam Nordhaus, Macroeconomics, Alih Bahasa Haris Munanandar, Dkk, Makroekonomi, Erlangga, Jakarta, 1996, Hlm.344
} 
perekonomian ${ }^{12}$. Menurut Wirasasmita $(\mathrm{dkk})^{13}$. Fiskal berhubungan dengan uang dan kredit, terutama keuangan pemerintah. Sementara Kebijakan Fiskal (fiskal policy) adalah kebijakan pemerintah mengenai pajak, hutang negara (public debt), pengadaan dan pembelanjaan dana pemerintah serta kebijakan-kebijakan tersebut menyangkut efek-efek yang ditimbulkannya terhadap kegairahan swasta dan terhadap perekonomian secara keseluruhan.

Menurut Abdul Mannan ${ }^{14}$. Kebijakan fiskal adalah langkah pemerintah untuk membuat perubahan-perubahan dalam sistem perpajakan atau dalam pembelanjaan, yang bertujuan untuk mengatasi masalah-masalah ekonomi yang dihadapi Negara. Kebijakan fiskal merupakan kebijakan yang diambil oleh pemerintah dalam rangka mengatur pendapatan dan pengeluaran Negara untuk mempengaruhi perekonomian agar lebih baik atau stabil. Kebijakan fiskal mempunyai peran yang sangat penting dalam perekonomian makro.

Kebijakan Fiskal bisa dikatakan salah satu kebijakan ekonomi makro yang sangat penting dalam rangka ${ }^{15}$ :

a. Membantu memperkecil fluktuasi dari siklus usaha.

b. Mempertahankan pertumbuhan ekonomi yang sustainable, kesempatan kerja yang tinggi

c. Membebaskan dari inflasi yang tinggi atau bergejolak

Saat ini, kebijakan fiskal menempati posisi yang sangat strategis dalam pembangunan perekonomian dalam sebuah Negara. Karena kebijakan fiskal mengalami perkembangan yang luas, bukan hanya saja untuk mengatasi pengangguran, tetapi lebih luas lagi sebagai kebijakan ekonomi luar negeri (ekonomi internasional). Sehingga kebijakan fiskal sering disebut juga sebagai "politik ekonomi". Apa lagi kebijakan fiskal di Negara-negara maju (terutama barat) sebagai syarat dalam meningkatkan pertumbuhan ekonominya.

\section{Zakat Sebagai Instrumen Fiskal Islam}

Al-Qur'an tidak memberikan perincian kebijakan fiskal. Akan tetapi, ada beberapa ajaran ekonomi dan prinsip-prinsip pengarah yang terekam dalam sunnah sebagai pengarah dan penjelasnya. Dengan demikian, sunnah Nabi menjadi sumber penting kedua keuangan publik dalam Islam setelah al-Qur'an.

Dalam Islam, kebijakan fiskal merupakan suatu kewajiban negara dan menjadi hak rakyat, sehingga kebijakan fiskal bukanlah semata-mata sebagai

\footnotetext{
${ }^{12}$ Richard A Musgrave dan Peggy B Musgrave, Kenangan Negara dalam teori dan praktek, Edisi 5,,Alih Bahasa Alfonsus Sirait) Erlangga, 1993,hlm.5

${ }^{13}$ Wirasasmita (dkk), Kamus Lengkap Ekonomi, Pioner Jaya, 1999, Bandung, halaman 177

${ }^{14} \mathrm{MA}$ Mannan, Islamics Economics, theory and practice, Alih Bahasa M.Nastangin, Teori dan Praktek Ekonomi Islam, cet VII, Pt Dana Bhakti Wakaf, Yogyakarta, 1995, Hlm.230

156 Ani Sri Rahayu, Pengantar Kebijakan Fiskal, Bumi Aksara, Jakarta, 2010,Hal. 2
} 
suatu kebutuhan untuk perbaikan ekonomi maupun untuk peningkatan kesejahteraan rakyat saja, akan tetapi lebih pada penciptaan mekanisme distribusi ekonomi yang adil. Karena hakikat permasalahan ekonomi yang melanda umat manusia adalah berasal dari bagaimana distribusi harta di tengahtengah masyarakat terjadi. Jadi uang publik dipandang sebagai amanah di tangan penguasa dan harus diarahkan pertama-tama pada lapisan masyarakat yang lemah dan orang-orang miskin, sehingga tercipta keamanan masyarakat dan kesejahteraan umum.

Al-Mawardi -seorang pemikir terkemuka abad ke-5 M berpendapat bahwa pelaksanaan imamah (kepemimpinan politik keagamaan) merupakan kekuasaan absolut dan pembentukannya merupakan suatu keharusan demi terpeliharanya agama dan pengelolaan dunia. Berkaitan dengan hal tersebut, negara memiliki peran aktif demi tereralisasinya tujuan material dan spiritual. Dalam Islam, terpenuhinya pekerjaan dan kepentingan publik bagi rakyat merupakan kewajiban keagamaan dan moral penguasa ${ }^{16}$.Tegaknya suatu Negara bergantung pada kemampuan pemerintah mengumpulkan pendapatan dan mendistribusikannya pada kebutuhan kolektif masyarakat. Dengan ini cukup jelas bahwa penguasa atau pemerintah memiliki peran penting dalam pengaturan keuangan publik, termasuk zakat. Hal ini juga yang dijelaskan oleh Abdullah M. Sadeq dalam buku Development issues in Islam yang menjelaskan bahwa negara memiliki peran sentral dalam menciptakan kondisi yang kondusif dalam pengelolaan zakat yang optimal ${ }^{17}$.

Ada beberapa karya fuqaha terdahulu yang membahas mengenai keuangan publik dan segenap kebijakannya. Satu di antaranya adalah kitab alKharaj. Karya monumental ini dinisbahkan kepada ahli fikih dan sarjana besar Qady Abu Yusuf. Dengan daya analisis yang tinggi, AbuYusuf berusaha menganalisis masalah keuangan dan menunjukkan beberapa kebijakan yang harus diadopsi untuk kesejahteraan rakyat ${ }^{18}$.Karya lain yang terkenal adalah alAmwal salah satu yang paling terkenal adalah karya Abu 'Ubaid, yang membahas masalah keuangan dan pengelolaan keuangan negara dalam konteks historis dan fikih.

Konsep keuangan publik yang dipraktikkan oleh Rasulullah SAW dan pemerintahan Islam sangat konsen terhadap kesesuaian antara pemasukan dan pengeluaran negara yang sesuai dengan aturan syariah. Sedangkan APBN dalam sistem saat ini tidak memperhatikan hal tersebut. Pemasukan dari berbagai sumber dilebur menjadi satu tanpa melihat dari mana asalnya apakah dari

${ }^{16}$ Ini sebagaimana dijelaskan oleh E. Ames dan R. Trap dalam The Birth and Death of Taxes Hypothesis: The Journal of Economic History. Lihat: Sabahuddin Azmi, Menimbang Ekonomi Islam, h. 162.

${ }^{17}$ Sadeq, M. Abdullah (ed).2006.Development Issues in Islam.Kuala Lumpur IIUM Press

18 Azmi,Sabahuddin,Menimbang Ekonomi Islam, h. 46. 
kepemilikan umum atau negara, dan memang demikian adanya aturannya. Setelah semua pemasukan dilebur menjadi satu, baru digunakan untuk berbagai pembiayaan negara.

\section{Zakat adalah Sumber utama Pendapatan Negara Islam}

Keuangan publik Islam masa awal telah membedakan sumber-sumber pendapatan dan keuangan negara (al-mawarid al-maliyah li al-dawlah). Berdasarkan perolehannya, sumber-sumber pendapatan negara tersebut menurut Abdul Wahhab Khalaf dapat dikategorikan menjadi dua, yakni yang bersifat rutin (dawriyyah) dan pendapatan insidental (ghayr dawriyyah). Pendapatan rutin negara terdiri dari zakat, kharaj (pajak bumi/tanah), jiayah (pajak jaminan keamanan atas non-Muslim), dan 'ushur (pajak ekspor dan impor). Sedangkan pendapatan tidak rutin adalah pemasukan dari sektor tak terduga seperti dari ghanimah dan fai' (harta rampasan perang), ma'adin (seperlima hasil tambang) dan rikaz (harta karun), harta peninggalan dari pewaris yang tidak mempunyai ahli waris, harta temuan dan segala bentuk harta yang tidak diketahui secara pasti pemiliknya ${ }^{19}$.

Mengenai sumber pendapatan negara (Baitul Mal) dapat dikelompokkan menjadi tiga kelompok: pertama, bersumber dari kalangan muslim (zakat mal, zakat fitrah, wakaf, nawaib, sedekah, dan amwal fadla). Kedua, penerimaan yang bersumber dari kalangan nonmuslim seperti jizyah, kharaj, dan ushur. Dan ketiga, penerimaan dari sumber lain seperti ghanimah, fai', uang tebusan, hadiah dari pimpinan negara lain dan pinjaman pemerintah baik dari kalangan muslim maupun nonmuslim. Lebih lengkap dapat dilihat pada tabel berikut

\section{Tabel 2.}

Sumber Penerimaan Negara pada Masa Rasulullah SAW dan Khulafaur Rasyidin

\begin{tabular}{|c|l|l|}
\hline NO & $\begin{array}{l}\text { SUMBER } \\
\text { PENERIMAAN }\end{array}$ & $\begin{array}{l}\text { TAHUN } \\
\text { DIBERLAKUKAN }\end{array}$ \\
\hline $\mathbf{1}$ & Zakat & $\begin{array}{l}\text { Diperintahkan tahun 2H dan diwajibkan } \\
\text { tahun 9 H }\end{array}$ \\
\hline $\mathbf{2}$ & Jisyah & Setelah tahun 7 H \\
\hline $\mathbf{3}$ & Kharaj & Setelah tahun 7 H \\
\hline $\mathbf{4}$ & Ushur & Setelah tahun 7 H \\
\hline $\mathbf{5}$ & Nawaib & - \\
\hline $\mathbf{6}$ & Pinjaman & - \\
\hline $\mathbf{7}$ & Wakaf & $\begin{array}{l}\text { Tahun 4 H, melalui penaklukan Bani } \\
\text { Nadhir }\end{array}$ \\
\hline
\end{tabular}

${ }^{19}$ Khalaf,Abd al-Wahhab. 1977. al-Siyasah al-Shar'iyyah . al-Munirah: Matba'ah al-Taqaddum. 


\begin{tabular}{|c|l|l|}
\hline $\mathbf{8}$ & Fai & Tahun 7 H atau 8 H \\
\hline $\mathbf{9}$ & Khums & Tahun 2 H, setelah perang Badar \\
\hline $\mathbf{1 0}$ & Amwal fadla & - \\
\hline $\mathbf{1 1}$ & Kaffarah & - \\
\hline
\end{tabular}

Sumber: Diolah dari beberapa literatur

Zakat adalah salah satu sumber pendapatan utama dalam negara Islam. ${ }^{20}$. Inti dari sumber keuangan negara dalam ekonomi yang islami adalah zakat. Pendapatan zakat didistribusikan untuk mustabik zakat yang meliputi delapan golongan, sebagaimana tercantum dalam QS. Al-Taubah (9): 60. Dana yang berasal dari zakat sama sekali tidak diperbolehkan untuk menarik laba atau modal pembangunan. Zakat sebagai sumber penerimaan utama memiliki potensi yang besar mengingat hukumnya yang wajib. Selain itu objek zakat dalam dunia modern saat ini bertambah luas dengan dimungkinkannya menarik zakat profesi selain zakat pertanian dan peternakan, zakat perusahaan dan sebagainya. Ajaran Islam dengan rinci telah menentukan syarat, kategori harta yang harus dikeluarkan zakatnya, dan lengkap dengan tarifnya. Pemerintah dapat memperluas objek yang wajib dizakati dengan berpegang pada nash-nash umum yang ada dan pemahaman terhadap realita modern.

\section{Pengentasan Kemiskinan adalah Pengeluaran Pemerintah Islam}

Terkait kebijakan pengeluaran pemerintah, pengendalian anggaran yang efisien dan efektif merupakan landasan pokok dalam kebijakan pengeluaran pemerintah, yang dalam ajaran Islam dipandu oleh kaidah-kaidah syariah dan penentuan skala prioritas. Para ulama terdahulu telah memberikan kaidahkaidah umum yang didasarkan dari al-Qur'an dan al-Sunnah dalam memandu kebijakan belanja pemerintah. Diantara kaidah-kaidah tersebut adalah: ${ }^{21}$

a. Pembelanjaan pemerintah harus dalam koridor maslabah.

b. Menghindari mashaqqah (kesulitan) dan mudarrat harus didahulukan ketimbang melakukan pembenahan.

c. Kaidah al-gbiurm bi al-gunmy, yaitu kaidah yang menyatakan bahwa yang mendapatkan manfaat harus siap menanggung beban (yang ingin beruntung harus siap menanggung kerugian).

d. Kaidah malayatimm al-wajib illa bibi fahuwa wajib. Yaitu kaidah yang menyatakan bahwa "sesuatu hal yang wajib ditegakkan, dan tanpa ditunjang oleh faktor penunjang

\footnotetext{
${ }^{20}$ Muhammad Saddam, Ekonomi Islam (Jakarta: Gramedia, 2002), hlm. 89.

${ }^{21}$ Umer Chapra, The Future of Economics: An Islamic Perspective (Jakarta: As-Syamil \& Gravika, 2001), h. 288.
} 
e. Lainnya tidak dapat dibangun, maka menegakkan faktor penunjang tersebut menjadi wajib hukumnya".

Adapun kaidah syariah yang berkaitan dengan belanja umum pemerintah mengikuti kaidah-kaidah yang telah disebutkan di atas. Secara rinci pembelanjaan negara harus didasarkan pada ${ }^{22}$ :

1. Prinsip efisiensi dalam belanja rutin. Yaitu mendapatkan sebanyak mungkin manfaat dengan biaya yang semurah-murahnya. Dengan demikian, akan jauh dari sifat mubazir dan kikir, di samping alokasinya harus sesuai syariah

2. Prinsip keadilan. Artinya, tidak hanya berpihak pada orang kaya saja dalam pembelanjaan.

3. Prinsip komitmen pada syariah dengan skala prioritas dari yang wajib, sunnah, mubah atau darurah, hajiyyah, dan kamaliyyah.

Mengenai pengeluaran negara selama masa pemerintahan Rasululullah SAW secara sistematis digunakan untuk hal-hal tertentu dan tersebut di bawah ini dalam tabel berikut ${ }^{23}$.

Tabel 3.

Pengeluaran dalam Pemerintah Islam

\begin{tabular}{|c|c|}
\hline Primer & Sekunder \\
\hline $\begin{array}{l}\text { Biaya pertahanan seperti } \\
\text { persenjataan, unta dan persediaan } \\
\text { Penyaluran zakat dan ushur kepada } \\
\text { yang berhak menerimanya } \\
\text { Pembayaran gaji untuk wali, qady, } \\
\text { guru, imam, muadzin dan pejabat } \\
\text { negara } \\
\text { Pembayaran upah para sukarelawan } \\
\text { Pembayaran utang negara } \\
\text { Bantuan untuk musafir (dari daerah } \\
\text { fadak) }\end{array}$ & $\begin{array}{l}\text { Bantuan untuk orang yang belajar } \\
\text { agama di Madinah } \\
\text { Jamuan untuk delegasi keagamaan, } \\
\text { utusan suku dan negara serta biaya } \\
\text { perjalanan } \\
\text { Hadiah untuk pemerintah negara lain } \\
\text { Pembebasan kaum muslimin yang } \\
\text { menjadi budak } \\
\text { Pembayaran denda atas mereka yang } \\
\text { terbunuh secara tidak sengaja oleh } \\
\text { pasukan kaum muslimin } \\
\text { Pembayaran utang orang yang } \\
\text { meninggal dalam keadaan miskin } \\
\text { Pembayaran tunjangan untuk orang } \\
\text { miskin }\end{array}$ \\
\hline
\end{tabular}

22 Ibid hlm. 295

23 Ibid., hlm. 51. 


\begin{tabular}{|l|l|}
\hline & Tunjangan untuk sanak saudara \\
Rasulullah \\
Pengeluaran rumah tangga Rasulullah \\
\\
saw \\
Persediaan darurat \\
\hline
\end{tabular}

Dalam Islam upaya mengatasi kemiskinan dilakukan melalui dua jalur, yaitu pertama mendorong orang miskin untuk bekerja keras dan kedua mendorong orang kaya untuk membantu orang miskin. Menurut Qardawi ${ }^{24}$, alQur'an datang untuk mengajak para hartawan untuk menginfakkan sebagian hartanya untuk orang lain termasuk yang utama adalah zakat. Tujuan pertama dari zakat adalah untuk memenuhi kebutuhan orang miskin. Fakir miskin adalah sasaran pertama dari pengeluaran zakat. Zakat telah membuktikan bahwa Islam sejak dulu memberikan perhatian terhadap penyelesaian persoalan kemiskinan dan memberikan perlindungan terhadap fakir miskin. Pemerintah mempunyai kewenangan mengatur efektivitas dan profesionalisme pengelolaan zakat. Dengan keberadaan zakat sebagai sedekah wajib, pemerintah dapat memaksa rakyatnya yang mampu dan telah mencapai syarat wajib zakat untuk menyediakan dana bagi penanggulangan kemiskinan melalui instrumen zakat ${ }^{25}$.

\section{Potensi Zakat di Indonesia dan Potensinya dalam Pengentasan Kemiskinan di Indonesia}

Indonsia memiliki potensi zakat yang besar di Indonesia. Menurut Didin, ketua BAZNAS jika terkoordinasi dengan baik, potensi zakat di Indonesia ini sangat besar. Menurut riset Baznas dan Fakultas Ekonomi Manajemen (FEM) IPB tahun 2011 menunjukkan bahwa potensi zakat nasional mencapai angka 3,4 persen dari total Produk Domestik Bruto (PDB). Dengan persentase ini, maka potensi zakat di negara kita setiap tahunnya tidak kurang dari Rp 217 triliun. Sedangkan khusus mengenai potensi zakat dari Giro Wadiah dan Deposito Mudharabah di perbankan syariah, penelitian tersebut menemukan bahwa potensi zakat keduanya mencapai masing-masing sebesar Rp 155 miliar dan Rp 739 miliar. Potensi yang besar ini tidak akan terealisasikan jika tidak disertai oleh semangat dan komitmen kerja sama dari semua pihak, baik dari kalangan pengambil kebijakan, dunia usaha dan masyarakat secara umum ${ }^{26}$.

${ }^{24}$ Qardhawi, Yusuf.2002.Teologi Kemiskinan: Doktrin Dasar dan Solusi Islam atas Problem Kemiskinan. Yogyakarta: Mitra Pustaka. Hlm. 30

${ }^{25}$ Rafiq,S.2003.Zakatt dan Pengentasan Kemiskiman.Jakarta:Global.hlm.23

${ }^{26}$ www.Baznas.go.id 
Jumlah penduduk Muslim di Indonesia, yaitu sekitar 86\% dari 250 juta jiwa, atau sekitar 200 juta jiwa. Jumlah ini menempatkan Indonesia sebagai berpenduduk Muslim terbesar di dunia. Arab Saudi yang 100\% Muslim saja hanya memiliki sekitar 30 juta jiwa ${ }^{27}$.

Membaiknya kondisi perekonomian bangsa yang tentu saja menjadi salah satu represenstasi dari kondisi perekonomian masyarakat (Muslim). Data BPS (Badan Pusat Statistik) menunjukkan bahwa selama tiga tahun terakhir, terjadi peningkatan Pendapatan Perkapita penduduk di Indonesia, yaitu besarnya pendapatan rata-rata penduduk di suatu negara. Sebagaimana diketahui bahwa pendapatan per kapita sering digunakan sebagai tolok ukur kemakmuran dan tingkat pembangunan sebuah negara, semakin besar pendapatan per kapitanya, semakin makmur negara tersebut. Berikut data perkembangan pendapatan perkapita Indonesia 3 tahun terakhir:

Tabel 4

Kenaikan Pendapatan Perkapita Penduduk Indonesia

\begin{tabular}{|l|l|l|}
\hline Tahun & Pendapatan Perkapita & Kenaikan dari tahun sebelumnya (\%) \\
\hline 2009 & 23,9 juta & $11,6 \%$ \\
\hline 2010 & 27,1 juta & $13,3 \%$ \\
\hline 2011 & 30,8 juta & $13,8 \%$ \\
\hline \hline
\end{tabular}

sumber:BPS

Jika dihitung per bulan, rata-rata pendapatan per kapita penduduk Indonesia sekitar Rp2,56 juta. Dengan dasar asumsi bahwa mayoritas penduduk adalah muslim, maka tentu saja kenaikan pendapatan sebagian besar terjadi pada keluarga muslim. Dan dapat dipahami jika disebutkan bahwa terjadi peningkatan jumlah kelas menengah di Indonesia. Beberapa pengamat bahkan secara kuantitatif menyatakan bahwa setidaknya terjadi peningkatan sekitar 50 juta orang kaya baru.

Dari dua faktor diatas saja, maka potensi Rp217 triliun pertahun sebagaimana hasil penelitian Kemenag dan Baznas di atas, merupakan sesuatu yang cukup realistis. Katakanlah, jika dari $86 \%$ jumlah masyarakat Muslim, sekitar 60\% merupakan muzakki, dan rata-rata membayar zakat sebesar Rp2 juta, maka zakat yang bisa terkumpul sekitar 248 Trilyun.

${ }^{27}$ Data lebih lanjut bisa dilihat di www.bps.go.id atau www.worldbank.or.id tentang komposisi jumlah penduduk muslim di Indonesia dan dunia 
Jika dibandingkan dengan total APBN Indonesia 2012 sebesar Rp1,418 triliun, maka potensi zakat adalah seperempatnya. Sebuah angka yang sangat besar untuk penguatan dan pengembangan ekonomi ummat. Bahkan beberapa pihak ada yang menyebut potensi zakat umat Indonesia sebenarnya adalah sepertiga dari APBN. Tentu jumlah ini sangat potensial untuk menutupi defisit APBN bahkan dapat mendorong surplus APBN jika diserap dan dikelola dengan optimal.

Adapun mengenai peran zakat dalam pengentasan kemiskinan sudah banyak dikemukakan dan diteliti oleh para ahli. Antara lain:

1. Menurut Qardhawi (1999) potensi zakat yang bisa dikumpulkan pada beberapa negara yang berpenduduk Muslim adalah minimal 6,3\% dari total GDP nya. Jika jumlah tersebut didistribusikan dengan baik, maka diperkirakan akan mencukupi untuk menanggulangi masalah kemiskinan sekaligus membantu pemerintah dalam pemerataan distribusi pendapatan (Sadeq, 2002).

2. Untuk penanggulangan kemiskinan, zakat diyakini bisa memicu pertumbuhan ekonomi. Seperti diungkapkan oleh Awan (1980, dikutip oleh Sadeq, 2002) zakat mendorong seseorang untuk menjadi lebih produktif melali distribusi harta.

3. Beik (2009) tentang program penanggulangan kemiskinan Dompet Duafa menunjukkan bahwa program tersebut mampu menurunkan jumlah orang miskin sebesar $10 \%$. Hasil analisa menunjukkan bahwa zakat mampu mengurangi jumlah keluarga miskin dari 84 persen menjadi 74 persen. Kemudian dari aspek kedalaman kemiskinan, zakat juga terbukti mampu mengurangi kesenjangan kemiskinan dan kesenjangan pendapatan, diindikasikan oleh penurunan nilai P1 dari Rp 540.657,01 menjadi Rp 410.337,06 dan nilai I dari 0,43 menjadi 0,33. Sedangkan ditinjau dari tingkat keparahan kemiskinan, zakat juga mampu mengurangi tingkat keparahan kemiskinan yang ditandai dengan penurunan nilai Indeks Sen (P2) dari 0,46 menjadi 0,33 dan nilai indeks FGT dari 0,19 menjadi 0,11 .

\section{Model Pengelolaan Zakat di Berbagai Negara dan di Indonesia}

Sejatinya, pengelolaan harta zakat sejak zaman Rasulullah sampai dengan kejatuhan khilafah Islamiah merupakan tanggung jawab pemerintah (Sadeq, 2002). Namun belakangan model pengelolaan zakat di beberapa negara Muslim menjadi bervariasi. Sadeq mengklasifikasikan dua model pengelolaan zakat yang ada pada saat Inl yaknl; dikelola oleh negara dan dikelola oleh swasta dibawah pengawasan negara. Negara-negara yang pengelolaan zakatnya dilakukan oleh negara antara lain Pakistan, Sudan \Saudi Arbia, Yaman, dan Malaysia. 
Sedangkan negara-negara yang melakukan pengelolaan zakat melalui swasta antara lain Kuwait dan Bangladesh dan Afrika Selatan (Ahmed, 2004).

Di Indonesia sendiri konsep pengelolaan zakat menerapkan penggabungan antara pengelolaan oleh negara dengan swasta sebagaimana diatur oleh Undang-undang No. 38 tahun 1999 tentang pengelolaan zakat kemudian amandemen pada UU No.23 tahun 2011.

\section{Kelemahan Pengelolaan Zakat di Indonesia}

Akan tetapi terdapat beberapa kelemahan dalam pengelolaan zakat dengan model ini di Indonesia (Herdianto,t.t), antara lain:

1. Kelemahan Pengelolaan Zakat dari Aspek Yuridis.; yakni permasalahan mengenai aspek regulasi yang kurang sempurna dan tumpang tindah satu sama lain

2. Kelemahan Pengelolaan Zakat dari Aspek Sosiologis.; yakni berkaitan dengan pola pikir masyarakat dan ketidakpercayaan masyarakat terhadap pemerintah sebagai pengelola zakat

3. Kelemahan Pengelolaan Zakat Dari Aspek Institusi Dan Manajemen Zakat.; yakni berkitan dengan proses pengumpulan dan pendistribusian dana zakat disamping itu posisi dan peran pelaksana badan pengelola zakat yang masih belum strategis. Disamping itu pengelolaan zakat yang kurang transparan dan akuntabilitas adalah salah satu penyebab kurang berkembangnya zakat di Indonesia

\section{Strategi Menjadikan Zakat sebagai Instrumen Kebijakan Fiskal di Indonesia untuk Pengentasan Kemiskinan}

\section{Pembenahan Regulasi Zakat di Indonesia}

Aspek regulasi merupakan salah satu aspek paling fundamental yang mendorong perkembangan zakat di tanah air. Sebenarnya zakat di Indonesia sudah mendapat perhatian yang cukup baik dari pemerintah terutama semenjak dikeluarkannya UU No 23 tahun 2011, akan tetapi akan tetapi beberapa aspek regulasi yang sudah ada perlu dikembangkan dan disempurnakan lagi agar pengelolaan zakat di tanah air semakin efektif dan strategis. Dalam Undang-Undang yang pertama kali tentang zakat, yakni Undang-Undang Nomor 38 Tahun 1999 tentang Pengelolaan Zakat, secara eksplisit menyebutkan bahwa pengelolaan zakat merupakan kegiatan perencanaan, pengorganisasian, pelaksanaan, dan pengawasan terhadap pengumpulan dan pendistribusian serta pendayagunaan zakat. Ini menunjukkan bahwa undang-undang tersebut harus dapat dijadikan sebagai landasan dalam mengatur lebih lanjut mengenai zakat, infaq dan shadaqah, sehingga hukum (peraturan perundang-undangan) dimaksud harus 
dipandang sebagai: a) alat rekayasa sosial/pembangunan (law as a tool of social engeneering); b) instrumen penyelesaian masalah (dispute resolution); dan c) instrumen pengatur perilaku masyarakat (social control). Meskipun UU terbaru mengenai zakat telah dibentuk, yakni UU No. 23 tahun 2011 tentang pengelolaan zakat, namun keberadaan UU terbaru ini masih belum cukup untuk menjadikan zakat sebagai sebuah kebijakan yang dapat memberikan efek pembangunan secara masif, karena masih dipandang sebagai kewajiban sukarela bukan kewajiban memaksa bagi tiap umat Islam.

Beberapa hal yang perlu dibenahi kembali dalam aturan perundangundangan mengenai zakat antara lain; Pertama, pengumpulan zakat, dalam hal ini disebutkan bahwa dalam pasal 21 ayat (1) disebutkan bahwa dalam rangka pengumpulan zakat, muzakeki melakukan perbitungan sendiri atas kewajiban zakatnya. Pasal ini secara eksplisit menyebutkan bahwa zakat hanya masih bersifat sukarela, belum merupakan kewajiban yang dipaksakan oleh negara. Padahal dalam sejarah Islam, zakat adalah kewajiban yang diambil atau dipaksa oleh negara bagi para wajib zakat. Meskipun dalam pasal 22 disebutkan bahwa zakat yang dibayarkan oleh muzaki kepada BAZNAS atau $L A Z$ dikurangkan dari penghasilan kena pajak namun kebijakan ini juga hanya merupakan langkah persuasif agar masyarakat lebih intens membayar zakat. Akan tetapi perlu disadari kembali bahwa langkah ini masih belum cukup menjadikan zakat sebagai obligatory sector.

Kedua, mengenai penyelenggaraan zakat. Saat ini badan yang bertugas dalam melaksanakan pengelolaan zakat adalah Badan Amil Zakat Nasional (BAZNAS) yang dibentuk oleh pemerintah. Dalam pasal 5 ayat (3) disebutkan bahwa $B A Z N A S$ merupakan lembaga pemerintab non struktural yang bersifat mandiri dan bertanggung jawab kepada Presiden melalui Menteri. Seharusnya lembaga yang mengurusi zakat harus lebih strategis lagi dan kuat secara kerangka struktural. Bila perlu zakat harus dibuat seperti pajak secara struktural, yakni dibentuk Direktoral Jenderal Pajak sehingga benar-benar kuat secara struktural dan kuat secara pelaksanaan. Selanjutnya dalam pasal 7 ayat (1) BAZNAS menyelenggarakan fungsi; perencanaan pengumpulan, pendistribusian, dan pendayagunaan zakat dengan kata lain penyelenggaraan fungsi pengumpulan, pendistribusian, dan pendayagunaan zakat masih bersifat terpisah dari kebijakan nasional sebagaimana halnya penyelenggaraan pajak. Meskipun dalam ayat (2) disebutkan bahwa dalam rangka melaksanakan tugas dan fungsinya, BAZNAS dapat bekerjasama dengan pibak terkait sesuai dengan peraturan perundang-undangan namun kerjasama yang ada sekarang masih belum bersifat strategis dalam mengeksplorasi para wajib zakat. Selama ini BAZNAS masih bekerjasama dengan pusat-pusat perbelanjaan atau bankbank syariah untuk mengumpulkan zakat sehingga zakat yang terkumpul masih bersifat zakat maal saja. Seharusnya BAZNAS bisa bekerjasama 
dengan kementerian lain yang lebih strategis, seperti kementerian perdagangan, kementerian, pertanian, atau pun kementerian kelautan dan perikanan untuk mengumpulkan zakat-zakat lainnya, seperti zakat pertanian, peternakan, dan sebagainya.

Ketiga, diversifikasi zakat tidak diikuti dengan strategi pengumpulan zakat sesuai dengan klasifikasi objek zakat. Dalam pasal 4 ayat (1) disebutkan bahwa zakat meliputi zakat maal dan zakat fitrah. Dan ayat (2) zakat maal sebagaimana dimaksud pada ayat (1) meliputi : a) emas, perak, dan logam mulia lainnya; b) uang dan surat berharga lainnya; c) perniagaan ; d) pertanian, perkebunan, dan kehutanan; e) peternakan dan perikanan; f) pertambangan; g) perindustrian; h) pendapatan dan jasa; dan i) rikaz. Padahal dalam pasal ini sudah jelas bahwa objek zakat sangat beragam, namun hingga saat ini porsi zakat yang masih dominan yang berhasil dikumpulkan oleh BAZNAS belum menyentuh zakat peternakan, pertanian, dan sebagainya. Keempat, permasalahan mengenai distribusi zakat. Dalam pasal 25, 25, dan 27 dalam strategi pendistribusian zakat masih belum terdapat penjelasan mengenai pendistribusian zakat secara nasional dan strategis. Artinya pendistribusian zakat masih bertumpu kepada kebijakan BAZNAS atau LAZ dan belum menjadi instrumen strategis dalam kebijakan fiskal nasional.

\section{Pembentukan Struktur dan Kerangka Kelembagaan yang Lebih Strategis}

Saat ini dalam struktur ketatanegaraan BAZNAS sebagai badan yang mengurus zakat secara nasional merupakan lembaga non struktural sehingga keberadaan lembaga ini belum memiliki kesetaraan dengan lembaga-lembaga negara yang keberadaannya dibawah kementerian. Hal ini tentu akan berdampak pada kurang optimalnya penyerapan zakat dari masyarakat. Oleh karena itulah tata organisasi dan manajemen zakat di tanah air harus dilakukan. Struktur dan manajemen zakat yang ada saat ini dinilai masih belum efektif dan efisien, selain itu inaccountability dan intransparancy lembaga zakat di Indonesia menjadi salah satu penyebab zakat di Indonesia terhambat untuk berkembang. Hal ini memang karena skema pengelolaan zakat di Indonesia merupakan gabungan dari pemerintah dan swasta. Jika kita bercermin pada sejarah, maka pada masa Rasulullah SAW dan pemerintahan Islam selanjutnya pengelolaan zakat dilakukan oleh negara, begitu pun juga yang dijelaskan oleh para pemikir Islam bahwa pengelolaan zakat merupakan tanggung jawab negara.nOleh karena itulah struktur pengelolaan dan manajemen zakat di Indonesia harus dibenahi. Adapun langkah yang dapat dilakukan adalah dengan bercermin atau mengambil contoh dari struktur tata organisasi kenegaraan yang sudah ada dan berkembang di tanah air.

Saat ini pajak adalah sumber pendapatan utama dan terbesar negara. Dari tahun ke tahun jumlah pajak yang berhasil dikumpulkan terus 
meningkat yang kemudian berimplikasi pada peningkatan kemampuan negara untuk membiayai program-program pembangunan negara. Ada baiknya jika zakat ingin diserap secara optimal oleh negara, maka strategi dalam pengumpulan dana zakat harus dibuat dan dikembangkan sebagaimana cara pengumpulan pajak oleh negara. Direktorat Jenderal Pajak adalah best practice yang dapat diadopsi oleh pemerintah dalam memungut dana zakat. Direktorat Jenderal Pajak adalah lembaga struktural yang berada di bawah kementerian keuangan Republik Indonesia, sehingga secara struktur dan wewenang lebih strategis dan bersifat memaksa dalam memungut dana pajak, berikut adalah gambaran struktur organisasi Direktorat Jenderal Pajak yang bisa diadopsi oleh negara

\section{Gambar 2.}

\section{Struktur Organisasi Direktorat Jenderal Pajak}

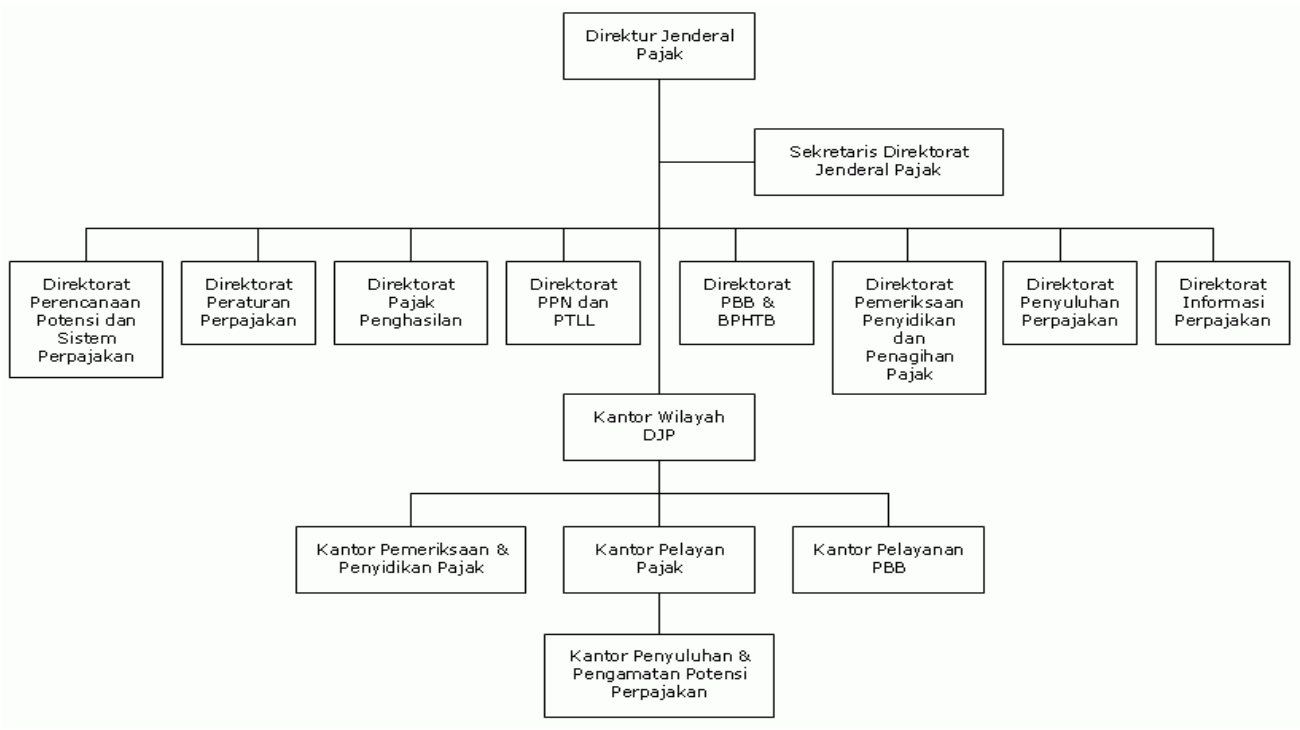

Sumber: Direktorat Jenderal Pajak

Struktur organisasi zakat di negara kita juga harus demikian jika ingin zakat sebagai instrumen kebijakan fiskal di Indonesia. Berikut gambaran atau ilustrasi jika lembaga zakat dijadikan sebagai lembaga struktural seperti Direktorat jenderal. Hal ini tentu ditujukan agar penyerapan dana zakat semakin efektif dan optimal. Dengan dijadikan zakat sebagai direktorat jenderal, maka pengumpulan dana zakat dan pengalokasiannya dapat lebih transparan dan akuntabilitas. Hal ini juga bertujuan agar dana zakat jelas dan dibedakan dengan sumber pendapatan negara lainnya. Selama ini dalam postur penerimaan negara 
di Indonesia dibedakan penerimaan dari sektor pajak dan non pajak, khususnya mengenai zakat, maka zakat pula harus mendapat wadah khusus sebagai salah satu sumber pemasukan negara. Hal ini tentu karena dalam aturan syariah, golongan-golongan yang berhak menerima dana zakat sudah ditentukan dalam al-qur'an, yakni delapan asnaf. Oleh karena itulah pos zakat harus dibedakan dengan lainnya. Sebagaimana yang dijelaskan oleh Khalaf bahwa sumbersumber pendapatan dalam konteks negara Islam memang berbeda, tidak boleh dikumpulkan dan dilebur menjadi satu sebagaimana praktek pada APBN saat ini. Pada masa Rasulullah SAW dan masa Abu Bakar Ra sebagai khalifah, seorang kepala negara bertindak juga sebagai kepala pemerintahan termasuk melakukan pemungutan zakat dan mendistribusikannya secara langsung. Dimana saat itu sistem yang ada pada baitul maal sebagai kas negara masih bersifat sederhana. Namun ketika masa Umar Ra. sistem baitul mal yang ada kemudian dilengkapi dengan sistem administrasi yang tertata baik dan rapi merupakan kontribusi terbesar yang diberikan khalifah Umar Ra kepada dunia Islam dan kaum muslimin ${ }^{28}$.

Dalam catatan sejarah, pembangunan institusi baitul mal dilatarbelakangi oleh kedatangan Abu Hurairah yang ketika itu menjabat sebagai Gubernur Bahrain dengan membawa harta hasil pengumpulan pajak kbaraj sebesar 500.000 dirham. Hal ini terjadi pada tahun $16 \mathrm{H}$. Kemudian khalifah Umar Ra bermusyawarah dengan para sahabatnya dan memutuskan untuk tidak mendistribusikan harta baitul mal tetapi disimpan sebagai cadangan, baik untuk darurat, pembayaran gaji para tentara maupun untuk berbagai kebutuhan umat lainnya. Inilah menjadi salah satu contoh mengapa lembaga yang mengurusi harta umat termasuk pengelolaan zakat harus dibangun, baik pembangunan secara fisik maupun sistemnya karena lembaga ini memiliki peran yang sangat strategis untuk pembangunan umat. Seperti itulah kelembagaan zakat di Indonesia disamping diperkuat dari posisi struktural, yakni menjadi Direktorat Jenderal sebagaimana Direktorat Jenderal Pajak juga harus memiliki bangunan fisik dan sistem yang memadai, baik di pusat pemerintahan, maupun di ibu kotaibukota provinsi sebagaimana yang dilakukan khalifah Umar Ra membangun bangunan lembaga baitul mal pertama kali didirikan di Madinah sebagai pusatnya kemudian diikuti dengan pendirian cabang-cabangnya disetiap ibu kota provinsi.

\section{1) Pengangkatan Kepala dan Pengurusan}

Untuk menangani lembaga baitul mal Khalifah Umar Ra mengangkat Abdullah Ibn Irqam sebagai bendahara negara dan Abdurrahman ibn Ubaid AlQari' sebagai dan Muayqad sebagai wakilnya. Dari sinilah kita mengetahui bahwa untuk mengurus harta umat termasuk zakat diperlukan pengangkatan

${ }^{28}$ M.A.Sabzwari,The Concept of Saving in Islam (Karachi:An NIT Publication,1982),hlm. 51 
seorang kepala, jika dalam konteks saat ini adalah pengangkatan direktur jenderal zakat, dan sekretaris jenderal zakat. Para pejabat ini hanya berperan sebagai pemegang amanah. Sedangkan di tingkat provinsi pejabat yang bertanggung jawab terhadap harta umat tidak bergantung kepada gubernur dan mereka mempunyai otoritas penuh dalam melaksanakan tugasnya serta bertanggung jawab secara langsung kepada pemerintah pusat dalam hal ini pusat pengelola baitul $\mathrm{mal}^{29}$.

\section{2) Pembuatan Departemen Pendukung}

Untuk mendistribusikan harta baitul mal, Khalifah Umar Ra mendirikan beberapa departemen yang dianggap perlu, seperti ${ }^{30}$ Departemen Pelayanan militer, departemen kehakiman dan eksekutif, departemen pendidikan dan departemen jaminan sosial.

Dari langkah yang dilakukan Umar Ra diatas, kita dapat mengetahui bahwa untuk menjalankan kebijakan diperlukan suatu departemen pendukung. Dalam hal ini jika zakat akan dijadikan sebagai instrumen kebijakan fiskal, maka selain infrastruktur dan sistem yang mendukung, maka diperlukan juga departemen-departemen atau divisi-divisi pendukung, seperti yang telah ada pada struktur Direktorat Jenderal Pajak saat ini, hanya saja diperlukan penyesuaian-penyesuaian agar sesuai dengan kebijakan zakat, adapun divisidivisi yang harus dibentuk tersebut antara lain:

a. Direktorat Informasi dan Dokumen.

Direktorat ini berfungsi untuk menyebarluaskan segala informasi yang berkaitan dengan zakat, baik kepada perorangan, institusi, lembaga pendidikan dan lain sebagainya. Bagian ini berfungsi juga sebagai sumber data para muzakki dan mustahik secara nasional untuk memudahkan pengumpulan dan distribusi zakat.

b. Direktorat Perencanaan Potensi dan Sistem Zakat

Direktorat ini berfungsi untuk mengidentifikasi potensi zakat secara nasional. Kemudian merencanakan sistem bagaimana pengumpulan dan pendistribusian zakat yang tepat dan efektif.

c. Direktorat Peraturan Zakat

Direktorat ini berfungsi untuk mengatur permasalahan-permasalahan yang berkaitan dengan legalitas, prosedur, dan ketentuan-ketentuan lain yang berkaitan dengan administrasi perzakatan nasional.

d. Direktorat Zakat Fitrah

Direktorat ini berfungsi untuk mengatur pengumpulan dan pendistribusian zakat fitrah. Hal ini dikarenakan zakat fitrah memiliki

\footnotetext{
${ }^{29}$ Irfan mahmud, Ekonomi Pemerintah Umar bin Khattab (Jakarta:Pustaka Firdaus,1997)hlm. 152153

${ }^{30}$ Afzalurrahman, Doktrin Ekonomi Islam (Yogyakarta:PT Dhana Bakti Zakat,1995)hlm 169-173 
tata cara dan waktu tersendiri dalam pengumpulan dan pendistribusian, sehingga diperlukan divisi khusus untuk mengaturnya.

e. Direktorat Zakat Mal

Direktorat ini bertujuan untuk mengatur pengumpulan dan pendistribusian zakat mal. Sebagaimana dalam ketentuan UndangUndang bahwa zakat mal terdiri dari a) zakat emas, perak, dan logam mulia lainnya b) uang dan surat berharga lainnya; c) perniagaan ; d) pertanian, perkebunan, dan kehutanan; e) peternakan dan perikanan; f) pertambangan; g) perindustrian; h) pendapatan dan jasa; dan i) rikaz. Maka direktorat ini harus bekerjasama dengan departemen-departemen terkait, seperti departemen pertanian, perindustrian dan sebagainya sesuai dengan objek zakat.

f. Direktorat Penyidikan dan Penagihan Zakat

Direktorat ini berfungsi untuk menyelidiki sudah wajib atau tidaknya seseorang untuk menunaikan zakat beserta besaran zakat yang wajib dia keluarkan. Selain itu juga divisi ini akan melakukan penagihan kepada wajib zakat (muzakki).

g. Direktorat Penyuluhan Zakat

Direktorat ini berfungsi untuk melakukan penyuluhan atau sosialisasi mengenai kewajiban mengeluarkan zakat bagi yang sudah mencapai syarat. Penyuluhan dilakukan baik secara online maupun secara off line dalam arti melakukan penyuluhan langsung ke tempat-tempat yang strategis, seperti kantor, universitas, perusahaan dan sebagainya.

Selain membentuk divisi-divisi pendukung, maka diperlukan juga pembukaan cabang-cabang di ibu kota-ibu kota provinsi di Indonesia. Hal ini sebagaimana yang telah dilakukan oleh Khalifah Umar bin Khattab Ra. Langkah ini selain bertujuan untuk memperluas akselerasi dan penyerapan zakat dari wajib zakat juga untuk mendukung optimalisasi dan efektivitas distribusi zakat.

Oleh karena itu di tiap-tiap ibu kota provinsi harus dibuka kantor wilayah Direktorat Jenderal Zakat sebagai perwakilan lembaga pusat di daerah. Untuk mendukung kinerja kantor perwakilan ini, maka diperlukan juga unit-unti pendukung, antara lain; kantor pemeriksaan dan penyidikan zakat yang berfungsi untuk menyelidiki potensi zakat yang ada di daerah. Kemudian kantor pelayanan zakat yang berfungsi untuk menerima zakat secara langsung dari masyarakat atau pihak-pihak yang ingin mengeluarkan zakatnya. Kemudian kantor unit pengumpul zakat yang berfungsi membuka stand-stand zakat di tempat-tempat strategis seperti pusat-pusat perbelanjaan, pusat perkantoran dan sebagainya. Dan kantor penyuluhan dan pengamatan potensi zakat yang berfungsi untuk melakukan penyuluhan atau sosialisasi zakat sekaligus melakukan pengamatan terhadap potensi-potensi zakat yang ada di daerah. 


\section{Memasukkan Zakat ke dalam Postur APBN}

Dalam sistem ekonomi fiskal Indonesia saat ini, sumber penerimaan pemerintah terdiri dari tiga bagian. Pertama, dan merupakan sumber penerimaan primer, berasal dari pungutan pajak. Kedua, berasal dari penerimaan negara bukan pajak. Ketiga, adalah hibah atau bantuan dan pinjaman luar negeri. Lebih sistematis dapat dilihat pada tabel berikut:

\section{Tabel 5}

\section{Pos-Pos Sumber Penerimaan Pemerintah Indonesia}

\begin{tabular}{|l|l|}
\hline No & Penerimaan Negara \\
\hline 1 & $\begin{array}{l}\text { Penerimaan Pajak } \\
\text { a. Pajak dalam negeri (pajak penghasilan, perseroan, pertambahan } \\
\text { nilai, penjualan, dsb) } \\
\text { b. Pajak perdagangan internasional }\end{array}$ \\
\hline 2 & $\begin{array}{l}\text { Penerimaan Negara Bukan Pajak } \\
\text { a. Penerimaan sumber daya alam } \\
\text { b. Bagian pemerintah atas laba BUMN } \\
\text { c. Penerimaan negara bukan pajak lainnya }\end{array}$ \\
\hline 3 & Hibah dan Bantuan Luar Negeri \\
\hline
\end{tabular}

\section{Tabel 6}

\section{Pos-Pos Pengeluaran Pemerintah Indonesia}

\begin{tabular}{|l|l|}
\hline NO & Pengeluaran Negara \\
\hline 1 & $\begin{array}{l}\text { a. Belanja Negara } \\
\text { b. Belanja pemerintah pusat } \\
\text { c. Belanja daerah }\end{array}$ \\
\hline 2 & $\begin{array}{l}\text { Pembiayaan } \\
\text { a. Dalam Negeri } \\
\text { b. Luar negeri } \\
\text { c. Tambahan pembiayaan hutang }\end{array}$ \\
\hline
\end{tabular}

Sumber: Nota Kenangan, APBN Indonesia 2018

Hampir tiap tahun penerimaan negara masih ditumpukan pada sektor pajak dan dari tahun ke tahun penerimaan dari pajak terus meningkat Ini berarti bahwa hampir 85\% lebih penerimaan APBN berasal dari pajak. Meskipun terjadi kenaikan penerimaan negara dari pajak dan non pajak namun peningkatan ini masih belum mampu menutup defisit anggaran APBN. Dengan demikian untuk meningkatkan penerimaan negara, maka zakat adalah alternatif yang tepat untuk dijadikan sebagai instrumen APBN, apalagi diperkirakan bahwa potensi zakat di Indonesia hingga Rp300 triliun, jumlah ini tentu sangat 
cukup untuk menutupi kebutuhan anggaran negara sehingga negara tidak perlu lagi berhutang karena defisit anggaran.

Jika zakat dimasukkan sebagai instrumen dalam kebijakan fiskal, maka zakat dalam postur APBN akan masuk ke dalam pos penerimaan bukan pajak. Hal ini karena pos zakat harus khusus dan diatur berdasarkan syariah, dana zakat tidak bisa digabung dan dilebur dengan dana lain, karena golongan yang berhak menerima zakat sudah jelas berdasarkan syariah, yakni delapan asnaf zakat.

\section{Tabel 7}

\section{Skenario Pos Penerimaan Zakat dalam Postur APBN}

\begin{tabular}{|l|l|}
\hline No & Penerimaan Negara \\
\hline 1 & $\begin{array}{l}\text { Penerimaan Pajak } \\
\text { a. Pajak dalam negeri (pajak penghasilan, perseroan, pertambahan } \\
\text { nilai, penjualan, dsb) } \\
\text { b. Pajak perdagangan internasional }\end{array}$ \\
\hline 2 & $\begin{array}{l}\text { Penerimaan Negara Bukan Pajak } \\
\text { a. Penerimaan sumber daya alam } \\
\text { b. Bagian pemerintah atas laba BUMN } \\
\text { c. Penerimaan negara bukan pajak lainnya } \\
\text { d. Penerimaan dari zakat (ilustrasi) }\end{array}$ \\
\hline 3 & Hibah dan Bantuan Luar Negeri \\
\hline
\end{tabular}

Untuk pos pengeluaran zakat, maka ketentuannya berdasarkan aturan syariah, yakni berdasarkan surah At-Taubah ayat 60 dan berdasarkan skala prioritas. Hal ini juga sudah tercantum di dalam UU No.23 tahun 2011 tentang zakat, bahwa distribusi zakat berdasarkan pasal 25 zakat wajib didistribusikan kepada mustabik sesuai dengan syariat Islam. Dan dalam pasal 26 pendistribusian zakat, sebagaimana yang dimaksud dalam pasal 25 dilakukan berdasarkan skala prioritas dengan memperhatikan prinsip pemerataan, keadilan, dan kewrilayahan. Kemudian dalam pasal 27 mengenai pendayagunaan zakat, dalam ayat (1) zakat dapat didayagunakan untuk. usaba produktif dalam rangka penanganan fakir miskin dan peningkatan kualitas umat. Dalam ayat (2) pendayagunaan zakat untuk usaha produktif sebagaimana pada ayat (1) dilakukan apabila kebutuban dasar mustahik sudab terpenubi.

Sehingga dalam hal ini untuk pos pengeluaran zakat adalah pada pos belanja pemerintah untuk pengentasan kemiskinan.

Tabel 8

Skenario Pos Pengeluaran Zakat dalam Postur APBN

\begin{tabular}{|l|l|}
\hline NO & Pengeluaran Negara \\
\hline 1 & $\begin{array}{l}\text { a. Belanja Negara } \\
\text { b. Belanja pemerintah pusat (pos pengeluaran zakat) }\end{array}$ \\
\hline
\end{tabular}




\begin{tabular}{|l|l|}
\hline & c. Belanja daerah \\
\hline 2 & Pembiayaan \\
& a. Dalam Negeri \\
& b. Luar negeri \\
& c. Tambahan pembiayaan hutang \\
\hline
\end{tabular}

Saat ini belanja negara untuk pengentasan kemiskinan cukup tinggi, yakni sebesar Rp115,5 triliun untuk sasaran penurunan kemiskinan menjadi sekitar 9,5-10,5 persen melalui beberapa program berikut;

- Pelaksanaan Program Keluarga Harapan (PKH), dalam bentuk bantuan tunai bersyarat dengan anggaran Rp2,8 T untuk keluarga miskin dengan syarat pendidikan dan kesehatan dengan sasaran 2,4 juta RTSM;

- Penyediaan beras dengan harga murah untuk rakyat miskin dengan anggaran Rp17,2 T untuk 15,5 juta RTS;

- Peningkatan pemberdayaan masyarakat melalui pelaksanaan program PNPM Mandiri, yang antara lain terdiri atas: (1) PNPM Perdesaan di 5.230 kecamatan (Rp8,0 T); dan (2) PNPM Perkotaan di 10.922 kelurahan $(\mathrm{Rp} 1,7 \mathrm{~T})$.

Jika zakat dimasukkan ke dalam instrumen kebijakan fiskal, maka pos pengeluarannya tentu yang paling utama dan prioritas adalah untuk pengentasan kemiskinan. Apabila dana pengentasan kemiskinan mampu ditutupi melalui dana zakat, maka alokasi dana penanggualangan kemiskinan yang ada dapat dialokasikan ke sektor lain, seperti sektor pendidikan, infrastruktur, ataupun kesehatan. Disamping itu dengan adanya pemasukan dari zakat dalam APBN, maka tentunya akan memperkecil peluang terjadinya defisit anggaran.

Dalam hal pendistribusian pendapatan zakat, Al-Mawardi menyatakan bahwa kewajiban negara untuk mendistribusikan zakat harta kepada orangorang fakir dan miskin hanya taraf pada sekedar untuk membebaskan mereka dari kemiskinan. Tidak ada jumlah tertentu untuk membantu mereka karena 'pemenuhan kebutuhan' merupakan istilah yang relatif. Untuk memenuhi kebutuhan hidupnya sehingga terbebas dari kemiskinan, seseorang bisa jadi hanya membutuhkan satu dinar, sementara yang lain mungkin membutuhkan seratus dinar ${ }^{31}$.

Dengan kata lain, peneluaran pemerintah untu pengentasan kemiskinan melalui dana zakat ditujukan untuk dua hal, pertama, digunakan untuk pemenuhan kebutuhan dasar masyarakat miskin, baik kebutuhan dasar mereka akan makanan, kesehatan, pendidikan, dan sebagainya. Kedua, jika kebutuhan dasar ini sudah terpenuhi, maka pemerintah wajib memberdayakan mereka agar mereka dapat mandiri dengan tujuan utama yakni mengeluarkan mereka dar jeratan kemiskinann.

31 Ali bin Muhammad Al-Mawardi,Al-Abkam Al-Sulthaniyyah (Kairo Maktabah alTaufiqiyyah,t.t.) hlm. 122. 
Disamping itu, Al-mawardi berpendapat bahwa zakat harus didistribusikan di wilayah tempat zakat itu diambil. Pengalihan zakat ke wilayah lain hanya diperbolehkan apabila seluruh golongan mustahik zakat di wilayah tersebut telah menerima zakat secara memadai. Kalau terdapat surplus, maka wilayah yang paling berhak menerimanya adalah wilayah terdekat dengan zakat tersebut diambil. Hal ini berarti sistem pengumpulan dan alokasi dana zakat harus terkonsentrasi dan berdasarkan skala prioritas, yakni dari daerah untuk daerah tersebut, namun jika terjadi surplus, maka barulah ditransfer ke daerah lain yang membutuhkan, yakni daerah terdekat. 


\section{Gambar 4.}

Model Rekonstruksi Zakat Sebagai Instrumen Kebijakan Fiskal untuk Pengentasan Kemiskinan di Indonesia

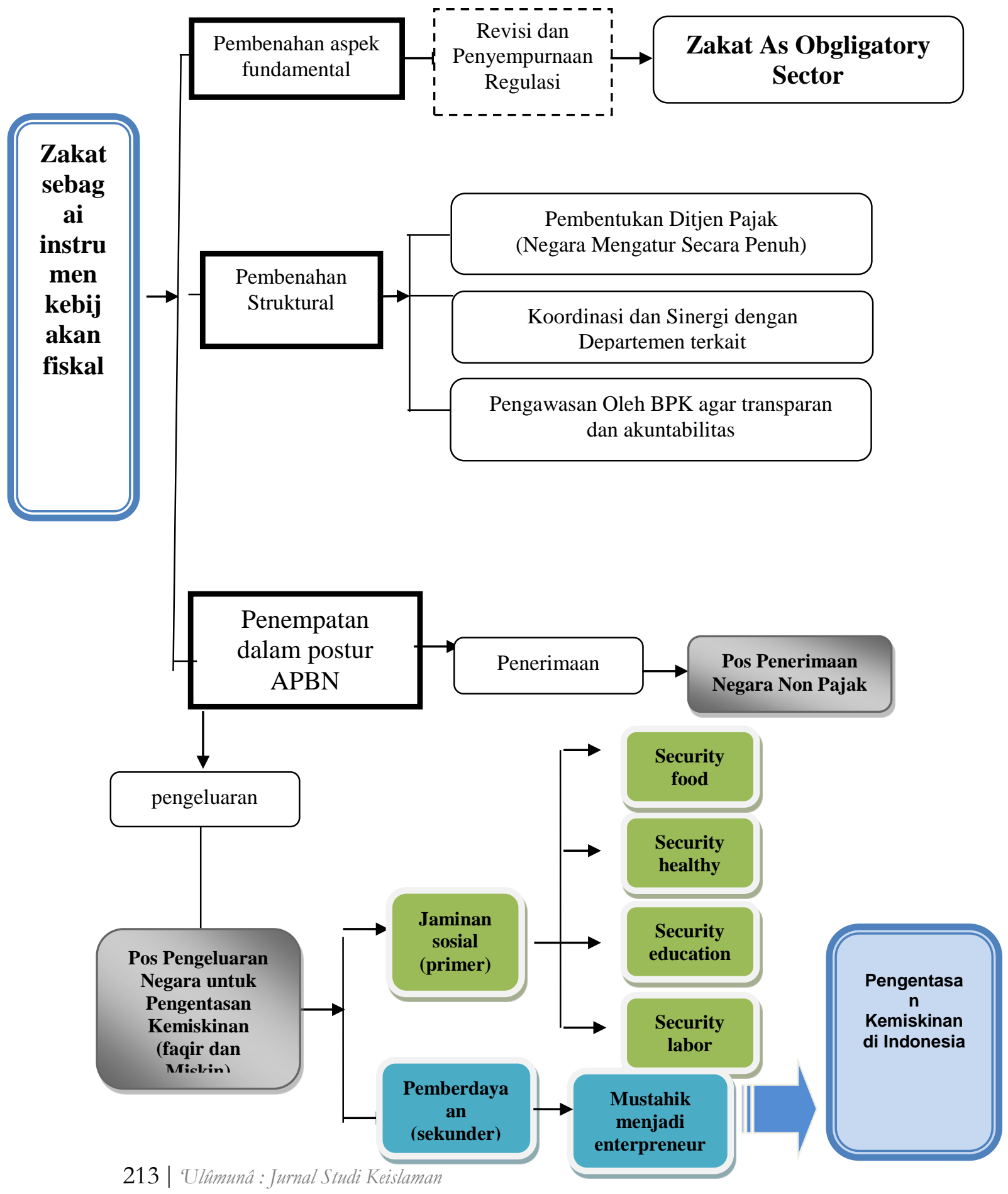




\section{Kesimpulan}

Pengeluaran Pemerintah dalam APBN Untuk Pengentasan Kemiskinan dari tahun ke tahun terus meningkat, namun selama ini tidak memberikan implikasinya besar dalam menurunkan Angka Kemiskinan.

Zakat adalah salah satu Instrumen Fiskal utama dalam Islam. Baik pada masa awal pemerintahan Islam pada masa Rasulullah dan pemerintahanpemerintahan Islam selanjutnya tidak pernah memisahkan zakat sebagai salah satu sumber utama pemasukan negara Islam. Disamping itu, zakat memiliki peran yang strategis dalam pengentasan kemiskinan karena sasaran penerima zakat, yakni kaum fakir dan miskin sudah ditetapkan oleh syariah.

Potensi Zakat di Indonesia sangat besar, diperkirakan per tahunnya hingga mencapai angka Rp300 triliun dan disisi lain zakat juga memiliki potensi dalam Pengentasan Kemiskinan di Indonesia karena tujuan utama zakat adalah memenuhi basic need mustahik hingga mereka terbebas dari jeratan kemiskinan. Sebagaimana yang dikemukakan oleh Beik (2009) bahwa zakat dapat mengurangi angka kemiskinan hingga 10 persen. Disamping mengurangi angka keparahan kemiskinan dan kesenjangan pendapatan antar masyarakat.

Meskipun potensi zakat di Indonesia sangat besar namun penyerapan zakat di Indonesia masih sangat rendah dan jauh dari harapan. Adapun faktorfaktor penyebab kurang optimalnya penyerapan dana zakat di Indonesia sangat beragam, mulai dari sikap skeptis masyarakat yang menganggap bahwa negara tidak perlu ikut campur dalam zakat, masalah infrastruktur lembaga pengumpul zakat hingga political will yang masih kurang.

Konsep zakat sebagai instrumen kebijakan fiskal pada dasarnya adalah bagaimana agar zakat dapat dimasukkan sebagai salah satu sumber pemasukan APBN sebagaimana halnya sumber lainnya seperti pajak, hibah dan sebagainya sehingga mampu meningkatkan pendapatan APBN dan meningkatkan pengeluaran negara pada sektor pengentasan kemiskinan. Adapun Strategi untuk menjadikan zakat sebagai instrumen kebijakan fiskal di Indonesia adalah melalui pembenahan regulasi dan penyempurnaan UU tentang zakat, kemudian lembaga yang mengurusi zakat secara nasional harus terstruktural menjadi direktorat jenderal dibawah kementerian keuangan agar daya serap zakat lebih optimal dan efektif. Dan terakhir adalah memasukkan zakat dalam postur penerimaan APBN yakni pada pos penerimaan bukan pajak dan pos pengeluaran zakat pada pos belanja negara untuk pengentasan kemiskinan.

\section{Saran}

Penulis berharap dari tulisan yang penulis susun ini dapat dijadikan sebagai pertimbangan bagi pemerintah Republik Indonesia dan pihak-pihak yang terkait agar menjadikan zakat sebagai salah satu instrumen kebijakan fiskal di negeri ini. Hal ini mengingat potensi zakat di Indonesia sangat besar terlebih 
mayoritas penduduk Indonesia adalah umat Islam. Dengan menjadikan zakat sebagai instrumen dalam kebijakan fiskal diharapkan penyerapan dana zakat dari penduduk wajib zakat (muzakki) dapat meningkat dan pendapatan negara pun akan meningkat kemudian akan berdampak pada pengurangan defisit APBN sehingga negara kita akan terhindar dari hutang. Disamping itu tentunya, diharapkan dengan meningkatnya pendapatan negara dari dana zakat, maka akan meningkat pula alokasi dana untuk pengentasan kemiskinan sehingga jumlah penduduk miskin di negeri ini dapat berkurang dengan signifikan. Dengan demikian political will dari para birokrat dan elite politik untuk merealisasikan zakat sebagai instrumen dalam kebijakan fiskal.

\section{DAFTAR PUSTAKA}

Afzalurrahman.1995.Doktrin Ekonomi Islam, Yogyakarta:PT Dhana Bakti Zakat Alawi, Nadhif. 2006. Pengaruh Anggaran Belanja Pembangunan Daerah Terbadap Kemiskinan Studi Kasus: Kab/Kota di Jawa Tengan tabun 2002-2004

Ali bin Muhammad Al-Mawardi,t.t,Al-Abkam Al-Sulthaniyyah.Kairo:Maktabah al-Taufiqiyyah

Ani Sri Rahayu.2010.Pengantar Kebijakan Fiskal,Jakarta: Bumi Aksara

Badan Pusat Statistik. 2010. Data Strategis

Basri, Faisal dan Munandar, Haris. 2009. Lanskap ekonomi Indonesia; kajian dan renungan terhadap masalah-masalah struktural,transformasi baru, dan prospek perekonomian Indonesia.Jakarta:Kharisma Putra Utama

Chapra, Umer.2001.The Future of Economics: An Islamic Perspective,Jakarta: AsSyamil \& Gravika

Hidayat, Ach. Syaful. 2010. Analisis Tata Kelola dan Distribusi Zakat Pada Lembaga Zakat, Infaq dan Shadaqoh (LAGZIZ) di Malang. (www.researchreport.umm.ac.id, diakses Mei 2019)

Irfan mahmud.1997.Ekonomi Pemerintah Umar bin Khattab,Jakarta:Pustaka Firdaus

Khalaf,Abd al-Wahhab. 1977. al-Siyasah al-Shar'iyyah . al-Munirah: Matba aeah alTaqaddum.

MA Mannan.1995.Islamics Economics, theory and practice, Alih Bahasa M.Nastangin, Teori dan Praktek Ekonomi Islam, cet VII, Yogyakarta:PT Dana Bhakti Wakaf

M.Suparmok.1997.Kenangan Negara Dalam Teori dan Praktek, Cet.VII, Yogyakarta:BPFE

Muhammad Saddam.2002.Ekonomi Islam,Jakarta: Gramedia

M.A.Sabzwari.1982.The Concept of Saving in Islam.Karachi:An NIT Publication

Paul A.Samuelson dan wiliam Nordhaus.1996. Macroeconomics, Alih Bahasa Haris Munanandar, Dkk, Makroekonomi ,Jakarta:Erlangga 
Rafiq,S.2003.Zakatt dan Pengentasan Kemiskiman.Jakarta:Global

Richard A Musgrave dan Peggy B Musgrave.1993. Kenangan Negara dalam teori dan praktek, Edisi 5,Alih Bahasa Alfonsus Sirait.Jakarta:Erlangga, 1993

Sabahuddin Azmi.2010.Menimbang Ekonomi Islam,Jakarta:Pustaka

Sharing, Mengelola Kenangan Publik Secara Islamin. Edisi 35 thn IV November 2009 Qardawi, Yusuf. 1999. Hukum Zakat. Bandung: Mizan.

Qardhawi, Yusuf.2002.Teologi Kemiskinan: Doktrin Dasar dan Solusi Islam atas Problem Kemiskinan. Yogyakarta: Mitra Pustaka

Todaro, Michael.P and Smith, Stephen C.2006. Pembangunan Ekonomi. Jakarta:Erlangga

Utomo, S.2006.Zakat dan Pembangunan.Jakarta:Perbit Pustaka

Wibowo, Ferry. 2009. Analisis Hubungan Alokasi Anggaran Program Penanggulangan Kemiskinan di Perkotaan (P2KP)Dengan Indeks Pembangunan Manusia dan Angka Kemiskinan.

Wirasasmita (dkk).1999.Kamus Lengkap Ekonomi,Bandung: Pioner Jaya.

http://www.baznas.go.id/Potensi Zakat di Indonesia, diakses 23 Februari 2013 http://www.fiskal.depkeu.go.id/Nota Keuangan/APBN Indonesia 2009, diakses 23 Oktober 2018 